\title{
PENGARUH BIOCHAR DAN PUPUK HIJAU Calopogonium mucunoides TERHADAP PERTUMBUHAN DAN HASIL KEDELAI (Glycine max L. Merril) SERTA MAKROFAUNA TANAH DI GAWANGAN TANAMAN KELAPA SAWIT
}

\author{
(The Effect of Biochar and Calopogonium mucunoides Green Fertilizer on Growth and Yield of \\ Soybean Plant (Glycine Max L. Merril) and Soil Macrofaunas at Inter-Row of Oil Palm Plant) \\ WINDY NATASHA PUTRI ${ }^{1}$, NELVIA ${ }^{1}$, IDWAR ${ }^{1}$ \\ 1 Jurusan Agroteknologi, Fakultas Pertanian, Universitas Riau \\ Kampus Bina Widya KM 12,5 Simpang Baru, Pekanbaru 28293 \\ Email: wndntshptr@gmail.com
}

\begin{abstract}
Oil palm plantations in Riau are very extensive and developed on marginal land. The utilization of oil palm plant for soybean cultivation is an alternative to increasing soybean production in Riau, because soybeans are classified as plants that tolerant to shade. The research aimed to study the interaction of biochar and Calopogonium mucunoides green fertilizer on growth and yield of soybeans and diversity of soil macrofauna in inter-rows of oil palm plant. The research was conducted in Pekanbaru, carried out in 7-year-old oil palm plant and soil science laboratory of the Faculty of Agriculture, University of Riau from April-August 2018. The research was done experimentally in a 3x3 factorial form using a completely randomized design (CRD). The first factor is biochar from coconut shell consists of 3 levels $\left(0,2,5\right.$ and 5 ton.ha $\left.{ }^{-1}\right)$. The second factor is Calopogonium mucunoides green fertilizer consists of 3 levels $\left(0,2,5\right.$ and 5 ton.ha $\left.{ }^{-1}\right)$. The parameters observed were plant height, pods per plant, percentage of pithy pods, seeds per plant, seed weight per plot, weight of 100 seeds, population density and relative density of soil macrofauna, and diversity index of soil macrofauna. The results showed 2,5 ton.ha ${ }^{-1}$ biochar followed by 2,5 ton.ha-1 Calopogonium mucunoides green fertilizer increased the number of pods per plant compared to controls. The total individuals and population of soil macrofauna increased at 5 ton.ha ${ }^{-1}$ biochar followed by 5 ton.ha-1 Calopogonium mucunoides green fertilizer with the family that was often found, namely Scarabaeidae. The diversity index of soil macrofauna is low.
\end{abstract}

Keywords: soybean, biochar, Calopogonium mucunoides green fertilizer, soil macrofaunas

\section{PENDAHULUAN}

Kedelai (Glycine max L. Merril) adalah tanaman palawija yang mempunyai peranan penting sebagai sumber protein nabati utama. Kedelai megandung protein 35\%, lemak $18 \%$ dan bahan gizi penting lain, seperti vitamin dan mineral (Cahyadi, 2007). Menurut Pusat Data dan Sistem Informasi Pertanian (2016), produksi kedelai di Riau dari tahun 2016 ke 2017 mengalami penurunan yaitu 2.654 ton menjadi 1.119 ton, dengan luas panen 2.207 ha menjadi 966 ha dan produktivitas 1,2 ton.ha-1 menjadi 1,15 ton.ha-1. Permintaan terhadap kedelai te-rus meningkat sejalan dengan pertambahan jumlah penduduk. Sementara itu produksi kedelai yang menurun belum mampu memenuhi kebutuhan kedelai di Riau.

Budidaya kedelai sebagai tanaman sela di bawah tegakan tanaman perkebunan khususnya kelapa sawit merupakan strategi untuk meningkatkan produksi kedelai nasional. Me- nurut Asadi et al. (1997), perkebunan kelapa sawit TBM 2-3 tahun memberikan naungan 33$50 \%$, sedangkan Sukaesih (2002) menambahkan pada perkebunan karet umur 1, 2 dan 4 tahun memberikan naungan berturut-turut $26 \%$, $67 \%$ dan $72 \%$. Semakin tinggi umur ta-naman kelapa sawit, maka semakin tinggi ting-kat naungan yang diberikan tanaman, bahkan tanaman kelapa sawit umur tahun diperkirakan memiliki tingkat naungan $\pm 70 \%$.

Tingkat naungan $70 \%$ akan memberikan sinar matahari sebesar $30 \%$. Salisbury dan Ross (1995) menyatakan bahwa cahaya mempunyai peranan yang sangat penting di dalam proses fisiologi tanaman, seperti fotosintesis, respirasi, pertumbuhan dan perkembangan, penutupan dan pembukaan stomata, serta berbagai pergerakan tanaman dan perkecam-bahan. Naungan dapat mengurangi enzim fotosintetik yang berfungsi sebagai katalisator dalam fiksasi $\mathrm{CO} 2$ dan menurunkan titik kompensasi cahaya (Cruz, 1997). 
Biochar dan pupuk hijau dapat digunakan untuk memperbaiki tingkat kemasaman tanah pada lahan kelapa sawit. Hasil penelitian Nurida et al. (2012) pada Typic Kanhapludult Lampung menunjukkan aplikasi biochar dengan takaran 2,5, 5 dan 7,5 ton. ha ${ }^{-1}$ meningkatkan berat pipilan biji kering jagung masing-masing sebesar $281,08 \%$, 400\% dan 524,32\% dibanding tanpa biochar. Penambahan biochar menambah ke-ersediaan hara dan resistensi hara (Atkinson dan Fitzgerald, 2010).

Jenis tanaman dari famili Leguminosa yang banyak digunakan sebagai pupuk hijau yaitu Calopogonium mucunoides yang banyak ditanam di perkebunan kelapa sawit di Riau (Rachman et al., 2016). Hasil penelitian Farni et al. (2011), pemberian Calopogonium mucunoides dan Pueraria javanica 5 dan 10 ton.ha ${ }^{-1}$ mampu meningkatkan hasil kedelai dan hasil tinggi dicapai pada pemberian Calopogonium mucunoides 10 toh.ha-1 yaitu 258,12 kg.ha-1. Pupuk hijau tanaman legum relatif mudah terdekomdosisi sehingga penyediaan haranya menjadi lebih cepat, bisa langsung diaplikasikan tanpa harus mengalami proses pengomposan lebih dulu.

Pupuk hijau merupakan sumber energi utama bagi kehidupan biota tanah, khususnya makrofauna tanah (Hakim et al., 1986). Makrofauna tanah berperan menjaga kesuburan tanah melalui perombakan bahan organik, distribusi hara, peningkatan aerasi tanah dan sebagainya, tetapi pada sisi lain juga dapat berperan sebagai hama berbagai jenis tanaman budidaya (Suin, 1997). Tujuan penelitian adalah untuk mempelajari interaksi biochar dan pupuk hijau Calopogonium mucunoides terhadap pertumbuhan dan hasil kedelai serta keragaman makrofauna tanah pada gawangan kelapa sawit.

\section{METODOLOGI}

Penelitian dilaksanakan di kota Madya Pekanbaru, pada kebun kelapa sawit dengan umur tanaman 7 tahun dan Laboratorium IImu Tanah Fakultas Pertanian Universitas Riau,
Kampus Bina Widya Tampan, Pekanbaru. Penelitian dilakukan dari bulan April-Agustus 2018.

Bahan yang digunakan adalah biochar tempurung kelapa yang telah diaktivasi dengan $\mathrm{NaOH}(1 \%)$, alkohol $70 \%$, pupuk hijau dari tanaman leguminosa (Calopogonium mucunoides), pupuk NPK Mutiara sebagai pupuk dasar, benih kedelai varietas Dega 1 dan legin. Alat yang digunakan adalah bor belgi, mesin cacah, timbangan digital, pinset, cawan petri, mikroskop dan alat tulis.

Penelitian dilaksanakan secara eksperimen dalam bentuk faktorial $3 \times 3$ menggunakan rancangan acak lengkap (RAL). Faktor pertama biochar tempurung kelapa terdiri dari 3 taraf (0, 2,5 dan 5,0 ton.ha-1). Faktor kedua do-sis pupuk hijau Calopogonium mucunoides ter-diri dari 3 taraf $\left(0,2,5\right.$ dan 5,0 ton.ha- $\left.{ }^{-1}\right)$. Se-tiap kombinasi perlakuan diulangan sebanyak 3 kali, sehingga didapatkan 27 unit percobaan.

Parameter yang diamati adalah tinggi tanaman, umur bebunga, umur panen, jumlah cabang primer, jumlah polong per tanaman, persentase polong bernas, jumlah biji per tanaman, berat biji per tanaman sampel, berat biji per plot, berat 100 biji, kepadatan populasi dan kepadatan relatif makrofauna tanah, serta indeks keanekaragaman jenis makrofauna tanah.

Data dianalisis dengan sidik ragam, sidik ragam yang berpengaruh nyata di uji lanjut dengan DNMRT pada taraf $5 \%$.

\section{HASIL DAN PEMBAHASAN}

\section{Tinggi Tanaman}

Tabel 1 menunjukkan pemberian biochar meningkatkan tinggi tanaman dibanding tanpa biochar atau biochar 5 ton.ha-1. Hal ini disebabkan pemberian biochar 2,5 ton.ha-1 mam-pu memperbaiki sifat kimia tanah pada gawa-ngan kelapa sawit sehing-ga ketersediaan un-sur hara pada lahan tersebut meningkat. Me-nurut Sukartono dan Utomo (2012), biochar tempurung kelapa mengandung $\mathrm{N}(0,34 \%), \mathrm{P}$ $(0,10 \%), \mathrm{K}(8,4 \%), \mathrm{Ca}(0,4 \%), \mathrm{Mg}(0,6 \%)$, serta kapasitas tukar kation $\left(11,78 \mathrm{cmol} . \mathrm{kg}^{-1}\right)$.

Tabel 1. Tinggi tanaman kedelai diantara tanaman kelapa sawit yang diaplikasikan biochar dan pupuk hijau Calopogonium mucunoides $(\mathrm{cm})$

\begin{tabular}{|c|c|c|c|c|}
\hline \multirow{2}{*}{$\begin{array}{l}\text { Biochar } \\
\left(\text { ton.ha }^{-1}\right)\end{array}$} & \multicolumn{3}{|c|}{ Pupuk hijau Calopogonium mucunoides (ton.ha-1) } & \multirow{2}{*}{ Rata-rata } \\
\hline & 0 & 2,5 & 5 & \\
\hline 0 & 47,60 & 52,33 & 66,00 & $55,31 a b$ \\
\hline 2,5 & 61,60 & 65,20 & 63,47 & 63,42 a \\
\hline 5 & 57,67 & 37,87 & 47,47 & $47,67 \mathrm{~b}$ \\
\hline Rata-rata & 55,62 & 51,80 & 58,98 & \\
\hline
\end{tabular}


Namun penambahan biochar 5 ton.ha-1 menurunkan tinggi tanaman, hal ini diduga semakin tinggi dosis biochar maka $\mathrm{pH}$ tanah akan semakin meningkat, sehingga meningkat-kan jumlah biota tanah karena $\mathrm{pH}$ tanah ter-sebut sesuai untuk pertumbuhannya. Pada kondisi hara $\mathrm{N}$ tersedia, akan terjadi immobili-sasi hara yang dilakukan oleh biota tanah ter-sebut untuk digunakan sebagai zat penyu-sun selnya sehingga terjadi persaingan hara an-tara biota tanah dengan tanaman. Menurut Risma (2012), sel hewan disusun oleh berba-gai senyawa kimia seperti protein yang tersu-sun atas nitrogen yang berperan sebagai penyusun membran sel.

Data tinggi tanaman kedelai pada tabel 1 berkisar antara 47,60-66 cm, tidak sesuai bila dibandingkan dengan tinggi tanaman pada deskripsi tanaman kedelai varietas Dega 1. Menurut Balai Penelitian Tanaman Aneka Kacang dan Umbi (2016), tinggi tanaman kedelai varietas Dega 1 adalah $53 \mathrm{~cm}$. Hal ini disebabkan lokasi penanaman kedelai yang tertutupi oleh tajuk kelapa sawit hingga $70 \%$, sehingga cahaya yang sampai untuk proses metabolisme tanaman hanya $30 \%$ menyebabkan pertumbuhan vegetatif tanaman terhambat dan mengalami etiolasi. Menurut Gatut dan Sundari (2011), etiolasi yang terjadi pada sebagian besar tanaman akibat naungan disebabkan karena adanya produksi dan distribusi auksin yang tinggi, sehingga merangsang pemanjangan sel yang mendorong meningkat-nya tinggi tanaman.

\section{Jumlah Polong per Tanaman}

Tabel 2 menunjukkan bahwa pemberian biochar 2,5 ton. ha ${ }^{-1}$ diikuti pupuk hijau Calopogonium mucunoides 2,5 ton.ha-1 ${ }^{-1}$ meningkat-kan jumlah polong per tanaman dibanding kontrol, tanpa pemberian biochar diikuti pupuk hijau Calopogonium mucunoides 2,5 ton.ha-1, ataupun pemberian biochar 5 ton.ha- ${ }^{-1}$ diikuti pupuk hijau Calopogonium mucunoides 2,5 atau 5 ton.ha-1, namun tidak ada perbedaan dibanding pemberian lain.

Tabel 2. Jumlah polong per tanaman kedelai diantara tanaman kelapa sawit yang diaplikasikan biochar dan pupuk hijau Calopogonium mucunoides (buah)

\begin{tabular}{ccccc}
\hline $\left.\begin{array}{c}\text { Biochar } \\
\text { (ton.ha }\end{array} \mathrm{A}^{-1}\right)$ & \multicolumn{2}{c}{ Pupuk hijau Calopogonium mucunoides (ton.ha ${ }^{-1}$ ) } & \multirow{2}{*}{ Rata-rata } \\
\cline { 2 - 4 } & 0 & 2,5 & 5 & $5,78^{\mathrm{b}}$ \\
2,5 & $4,00^{\mathrm{c}}$ & $4,60^{\mathrm{bc}}$ & $8,73^{\mathrm{a}}$ & $8,02^{\mathrm{a}}$ \\
5 & $8,20^{\mathrm{ab}}$ & $9,20^{\mathrm{a}}$ & $6,67^{\mathrm{abc}}$ & $5,78^{\mathrm{b}}$ \\
\hline Rata-rata & $6,07^{\mathrm{abc}}$ & $4,60^{\mathrm{bc}}$ & $4,47^{\mathrm{bc}}$ & \\
\hline
\end{tabular}

Keterangan: Angka pada baris dan kolom yang diikuti oleh huruf kecil yang sama menunjukkan berbeda tidak nyata menurut uji DNMRT pada taraf $5 \%$.

Berdasarkan hasil analisis kimia tanah sebelum aplikasi perlakuan, kandungan $\mathrm{P}$ total tanah sebesar $31,814 \mathrm{mg} 100 \mathrm{~g}^{-1}$ (sedang). Pemberian biochar dengan pupuk hijau Calopogonium mucunoides masing-masing 2,5 ton.ha-1 diduga mampu memperbaiki sifat fisik tanah menjadi lebih baik dan menambah ketersediaan hara $\mathrm{P}$ di dalam tanah, sehingga ketersediaan hara tercukupi untuk pertumbuhan tanaman terutama pertumbuhan polong tanaman.

Hasil analisis kandungan hara pada Calopogonium mucunoides menunjukkan bahwa kandungan hara $\mathrm{N}(3,47 \%), \mathrm{P}(0,18 \%), \mathrm{K}$ $(1,79 \%)$, Ca $(0,73 \%)$ dan Mg (0,22\%) (Purwanto, 2010). Menurut Gani (2009), biochar bila digunakan sebagai bahan pembenah tanah bersama pupuk organik dan anorganik dapat meningkatkan retensi hara bagi tanaman karena sifatnya yang memiliki daya serap hara yang tinggi dan persisten dalam tanah.

Pemberian biochar 5 ton.ha- ${ }^{-1}$ diikuti pupuk hijau dosis $0,2,5$ atau 5 ton.ha-1 menurunkan jumlah polong per tanaman, hal ini diduga penambahan biochar 5 ton.ha-1 dapat meningkatkan $\mathrm{pH}$ yang diikuti dengan meningkatnya jumlah biota tanah karena $\mathrm{pH}$ tanah tersebut sesuai untuk pertumbuhannya. Pada kondisi hara $P$ tersedia, akan terjadi immobilisasi hara yang dilakukan oleh biota tanah tersebut untuk digunakan sebagai zat penyusun selnya sehingga terjadi persaingan hara antara biota tanah dengan tanaman. Menurut Menurut Risma (2012), sel hewan disusun oleh berbagai senyawa kimia seperti mineral yang tersusun atas fosfor dan kalsium yang berfungsi sebagai komponen struktural sel, pemeliharaan fungsi metabolisme dan pengatur kerja enzim.

\section{Persentase Polong Bernas}

Tabel 3 menunjukkan persentase polong bernas tergolong rendah yaitu berkisar 83,59$93,71 \%$. Berdasarkan hasil analisis kimia tanah unsur $P$ di dalam tanah tergolong sedang yaitu berkisar $31,814-39,53 \mathrm{mg} 100 \mathrm{~g}^{-1}$, sehingga pentranslokasian fotosintat ke biji belum optimal. Menurut Pahan (2006), P diper-lukan sebagai sumber energi karena merubah ADP menjadi ATP pada proses translokasi hasil fotosintesis. Selain itu, kondisi lahan yang ternaungi menyebabkan proses fotosintesis berjalan tidak optimum sehingga hasil fotosintesis berupa fotosintat yang berguna dalam pembentukkan biji menjadi tidak optimal. Hal ini 
sesuai dengan pendapat Osumi et al. (1998), tanaman kedelai yang tumbuh di ling-kungan ternaungi akan terjadi penurunan akti-fitas fotosintesis, sehingga alokasi fotosintat ke organ reproduksi menjadi lebih berkurang.

Tabel 3. Persentase polong bernas tanaman kedelai diantara tanaman kelapa sawit yang diaplikasikan biochar dan pupuk hijau Calopogonium mucunoides (\%)

\begin{tabular}{lcccc}
\hline \multirow{2}{*}{$\begin{array}{c}\text { Biochar } \\
\text { (ton.ha }{ }^{-1} \text { ) }\end{array}$} & \multicolumn{2}{c}{ Pupuk hijau Calopogonium mucunoides (ton.ha ${ }^{-1}$ ) } & \multirow{2}{*}{ Rata-rata } \\
\cline { 2 - 4 } & 0 & 2,5 & 5 & \\
\hline 0 & 91,27 & 89,74 & 93,71 & 91,57 \\
2,5 & 89,85 & 92,12 & 93,10 & 91,69 \\
5 & 92,87 & 83,82 & 83,59 & 86,76 \\
\hline Rata-rata & 91,33 & 88,56 & 90,13 & \\
\hline
\end{tabular}

\section{Jumlah Biji per Tanaman}

Tabel 4 menunjukkan bahwa pemberian biochar 2,5 ton.ha- ${ }^{-1}$ meningkatkan jumlah biji per tanaman dibanding tanpa biochar atau biochar 5 ton.ha ${ }^{-1}$. Berdasarkan hasil analisis kimia tanah sebelum aplikasi perlakuan, kandungan $P$ total tanah sebe-sar 31,814 mg. $100 \mathrm{~g}^{-1}$ (sedang).

Tabel 4. Jumlah biji per tanaman kedelai diantara tanaman kelapa sawit yang diaplikasikan biochar dan pupuk hijau kalopogonium (buah)

\begin{tabular}{ccccc}
\hline Biochar & \multicolumn{3}{c}{ Pupuk hijau kalopogonium (ton.ha-1 ${ }^{-1}$ ) } & \multirow{2}{*}{ Rata-rata } \\
\cline { 2 - 4 }$\left(\right.$ ton.ha $\left.^{-1}\right)$ & 0 & 2,5 & 5 & $10,44^{\mathrm{b}}$ \\
\hline 0 & 7,20 & 7,93 & 16,20 & $14,75^{\mathrm{a}}$ \\
2,5 & 14,60 & 17,53 & 12,13 & $9,84^{\mathrm{b}}$ \\
\hline 5 & 10,53 & 8,00 & 11,00 & \\
\hline
\end{tabular}

Keterangan: angka pada kolom yang diikuti oleh huruf kecil yang sama menunjukkan berbeda tidak nyata menurut uji DNMRT pada taraf $5 \%$.

Pemberian biochar 2,5 ton.ha ${ }^{-1}$ diduga dapat memperbaiki sifat fisik tanah pada lahan kelapa sawit sehingga akar tanaman mampu memaksimalkan penyerapan hara di dalam tanah dengan baik untuk pembentukan biji kedelai. Menurut Ogawa (1994), penambahan biochar pada tanah pertanian dapat menambah retensi hara (sifat fisik), dan menambah retensi air (sifat fisik).

Pemberian biochar menjadi 5 ton.ha ${ }^{-1}$ menurunkan jumlah biji per tanama, hal ini semakin meningkat dosis biochar maka $\mathrm{pH}$ tanah meningkat, sehingga jumlah biota tanah ikut meningkat karena $\mathrm{pH}$ tanah tersebut sesuai untuk pertumbuhannya. Pada kondisi hara $\mathrm{P}$ tersedia, akan terjadi immobilisasi hara yang dilakukan oleh biota tanah tersebut untuk digunakan sebagai zat penyusun selnya sehingga terjadi persaingan hara antara biota tanah dengan tanaman. Menurut Novak et al. (2009), penambahan biochar mampu meningkatkan $\mathrm{pH}$ tanah dan kapasitas tukar kation (KTK) tanah.

\section{Berat $100 \mathrm{Biji}$}

Tabel 5 menunjukkan bahwa be-rat 100 biji tanaman kedelai berkisar antara 9,79-17,17 g. Berat 100 biji menunjukkan nilai yang tidak sesuai bila dibandingkan dengan bobot 100 biji pada deskripsi tanaman kedelai varie-tas Dega 1. Menurut Aneka Tanaman Kacang dan Umbi (2016), bobot 100 biji tanaman kedelai varietas Dega 1 adalah $22,98 \mathrm{~g}$.

Tabel 5. Berat 100 biji tanaman kedelai diantara tanaman kelapa sawit yang diaplikasikan biochar dan pupuk hijau Calopogonium mucunoides (gram)

\begin{tabular}{ccccc}
\hline Biochar & \multicolumn{2}{c}{ Pupuk hijau Calopogonium mucunoides (ton.ha-1) } & \multirow{2}{*}{ Rata-rata } \\
\cline { 2 - 4 } (ton.ha $^{-1}$ ) & 0 & 2,5 & 5 & 12,10 \\
\hline 0 & 9,79 & 11,69 & 14,82 & 15,89 \\
2,5 & 15,76 & 17,17 & 14,74 & 13,55 \\
\hline 5 & 16,06 & 10,39 & 14,22 & \\
\hline Rata-rata & 13,87 & 13,08 & 14,59 & \\
\hline
\end{tabular}

Hal ini disebabkan karena tanaman kedelai yang ternaungi menyebabkan terham-batnya laju fotosintesis sehingga proses pem-bentukan polong dan pengisian biji terhambat, ukuran biji yang dihasilkan akan menjadi ber-variasi dan mempengaruhi berat biji tersebut. Hal ini sesuai dengan pendapat Osumi et al. (1998) intensitas cahaya $50 \%$ berpengaruh nyata terhadap bobot 100 biji. Tanaman yang mendapat intensitas cahaya $50 \%$ akan terjadi penurunan aktifitas 
fotosintesis, sehingga alo-kasi fotosintat ke organ reproduksi menjadi berkurang maka akan menyebabkan bobot biji menjadi lebih ringan.

\section{Berat Biji per Plot}

Tabel 6 menunjukkan bahwa berat biji per plot tanaman kedelai berkisar antara 12,138,28 g.plot $^{-1}$ atau setara dengan $61-141 \mathrm{~kg}$. ha1. Berat biji per plot tidak sesuai bila dibandingkan dengan hasil biji pada deskripsi tanaman kedelai varietas Dega 1. Menurut Balai Penelitian Tanaman Aneka Kacang dan Umbi (2016), hasil biji tanaman kedelai varietas Dega 1 adalah 2,78 ton.ha- ${ }^{-1}$ atau setara $2.780 \mathrm{~kg} \cdot \mathrm{ha}^{-1}$.
Hal ini disebabkan rendahnya intensitas cahaya matahari pada lokasi penelitian akibat dari tajuk tanaman kelapa sawit yang menutupi tanaman kedelai sehingga tanaman tidak mampu berfotosintesis dengan baik yang menyebabkan pembentukan biji dan pengisian polong terhambat.

Hal ini sesuai dengan pendapat Trikoesoemaningtyas et al. (2008) tanaman yang ternaungi akan menyebabkan kemampuan penyimpanan karbohidrat yakni biji akan berkurang. Intensitas cahaya rendah dapat menghambat fotosintesis yang mana hasil fotosintat berkurang sehingga mempengaruhi pertumbuhan dan hasil kedelai.

Tabel 6. Berat biji per plot tanaman kedelai diantara tanaman kelapa sawit yang diaplikasikan biochar dan pupuk hijau Calopogonium mucunoides (gram)

\begin{tabular}{ccccc}
\hline Biochar & \multicolumn{2}{c}{ Pupuk hijau Calopogonium mucunoides (ton.ha ${ }^{-1}$ ) } & \multirow{2}{*}{ Rata-rata } \\
\cline { 2 - 4 } (ton.ha $^{-1}$ ) & 0 & 2,5 & 5 & 18,35 \\
\hline 0 & 12,13 & 14,65 & 28,29 & 24,21 \\
2,5 & 26,09 & 26,67 & 19,86 & 18,83 \\
\hline 5 & 21,53 & 13,46 & 21,47 & \\
\hline Rata-rata & 19,92 & 18,26 & 23,21 & \\
\hline
\end{tabular}

Sejalan dengan itu Jomol et al. (2000) menambahkan faktor penting yang dapat mempengaruhi hasil kedelai adalah cahaya yang diterima oleh tanaman dan apabila tanaman kedelai ternaungi dengan intensitas naungan $30 \%$ dapat menurunkan hasil sebesar $30-50 \%$.

\section{Identifikasi dan Klasifikasi Makrofauna Tanah}

Famili makrofauna tanah yang ditemukan yaitu Cryptopidae (kaki seratus), Formicidae (semut hitam), Gryllidae (cengkerik), Lumbricidae (cacing tanah) dan Scarabaeidae (kumbang) (Tabel 7). Scarabaeidae yang ditemukan berupa larva dan kumbang dewasa.

Tabel 7 menunjukkan bahwa makrofauna yang ditemukan pada areal tanaman kedelai di gawangan mati kelapa sawit yang diaplikasian dengan biochar maupun tanpa biochar pemberian pupuk hijau Calopogonium mucunoides maupun tanpa pupuk hijau memiliki jumlah dan famili makrofauna tanah yang berbeda. Hal ini disebabkan kandungan bahan organik dalam tanah berbeda-beda pada setiap pemberian.

Hasil analisis kimia tanah kandungan Coganik sebelum pem-berian biochar atau pupuk hijau Calopogonium mucunoides yaitu 1,22\%, sedangkan setelah pemberian biochar 5 ton.ha${ }^{1}$ diikuti pupuk hijau Calopogonium mucunoides 5 ton.ha-1 C-organik meningkat menjadi 1,67\%. Hal ini sesuai dengan pen-dapat Wulandari et al. (2007) peningkatan ma-krofauna tanah disebabkan oleh meningkatnya kandungan bahan organik dalam tanah yang dapat dimanfaatkan oleh makrofauna sebagai sumber makanan, semakin tinggi tingkat ketersediaan bahan organik maka semakin tinggi jumlah makrofauna yang ditemukan dalam tanah.

\section{Kepadatan Populasi (K) dan Kepadatan Relatif (KR) Makrofauna Tanah}

Kepadatan populasi dan kepada-tan relatif makrofauna tanah dihitung untuk membandingkan antara jumlah makrofauna tanah dengan makrofauna tanah lainnya. Kepadatan populasi makrofauna tanah sangat penting diukur untuk menghitung produktivitas dari makrofauna tanah dan kepadatan relatif dihitung untuk membandingkan kepadatan suatu jenis dengan kepadatan semua jenis yang terdapat dalam sampel unit tersebut (Suin, 2005).

Pemberian biochar 5 ton. ha ${ }^{-1}$ diikuti pupuk hijau Calopogonium mucunoides 5 ton.ha-1 memiliki kepadatan populasi makrofauna lebih tinggi dibanding kontrol dan pemberian lain-nya (Tabel 7). Meningkatnya kepadatan populasi ma-krofauna tanah pada lahan yang diberi biochar disebabkan karena biochar memiliki pori-pori yang berguna sebagai habitat makrofauna tanah, sedangkan pupuk hijau Calopogonium mucunoides dapat meningkatkan ketersediaan bahan organik yang berguna sebagai sumber energi untuk makrofauna tanah. Menurut Laird (2008), biochar yang berpori menjadi tempat berkembangnya organisme tanah sehingga memicu bertambahnya populasi organisme tanah. 
Tabel 7. Total individu dan jumlah famili makrofauna tanah diantara tanaman kelapa sawit yang diaplikasikan biochar dan pupuk hijau Calopogonium mucunoides

\begin{tabular}{|c|c|c|c|c|c|c|c|c|c|}
\hline \multirow[b]{2}{*}{ Famili makrofauna tanah } & \multicolumn{3}{|c|}{ Tanpa biochar } & \multicolumn{3}{|c|}{ 2,5 ton.ha-1 biochar } & \multicolumn{3}{|c|}{5 ton. ha- ${ }^{-1}$ biochar } \\
\hline & $\begin{array}{c}\text { Tanpa } \\
\text { PHM }\end{array}$ & $\begin{array}{c}\text { 2,5 ton.ha-1 } \\
\text { PHM }\end{array}$ & $\begin{array}{c}5 \text { ton.ha-1 }^{-1} \\
\mathrm{PHM}\end{array}$ & $\begin{array}{c}\text { Tanpa } \\
\text { PHM }\end{array}$ & $\begin{array}{c}\text { 2,5 ton.ha-1 } \\
\text { PHM }\end{array}$ & $\begin{array}{c}5 \text { ton.ha }^{-1} \\
\mathrm{PHM}\end{array}$ & $\begin{array}{c}\text { Tanpa } \\
\text { PHM }\end{array}$ & $\begin{array}{c}\text { 2,5 ton.ha-1 } \\
\text { PHM }\end{array}$ & $\begin{array}{c}5 \text { ton.ha }^{-1} \\
\text { PHM }\end{array}$ \\
\hline Cryptopidae & 2 & 2 & 1 & 2 & 1 & 1 & - & 1 & 4 \\
\hline Formicidae & - & - & 1 & - & - & - & - & 1 & 1 \\
\hline Gryllidae & - & - & - & - & - & - & - & - & 1 \\
\hline Lumbricidae & 3 & 1 & 2 & 2 & 5 & 5 & 5 & - & 3 \\
\hline Scarabaeidae & 2 & 7 & 3 & 7 & 6 & 1 & 1 & 7 & 10 \\
\hline Total individu & 7 & 10 & 7 & 11 & 12 & 7 & 6 & 9 & 19 \\
\hline Jumlah famili & 3 & 3 & 4 & 3 & 3 & 3 & 2 & 3 & 5 \\
\hline
\end{tabular}

Keterangan: PHM = Pupuk hijau Calopogonium mucunoides

Tabel 8. Kepadatan populasi dan kepadatan relatif makrofauna tanah diantara tanaman kelapa sawit yang diaplikasikan biochar dan pupuk hijau Calopogonium mucunoides

\begin{tabular}{|c|c|c|c|c|c|c|c|c|c|c|c|c|c|c|c|c|c|c|}
\hline \multirow{3}{*}{$\begin{array}{l}\text { Famili makrofauna } \\
\text { tanah }\end{array}$} & \multicolumn{6}{|c|}{ Tanpa biochar } & \multicolumn{6}{|c|}{ 2,5 ton ha $^{-1}$ biochar } & \multicolumn{6}{|c|}{5 ton.ha-1 biochar } \\
\hline & \multicolumn{2}{|c|}{$\begin{array}{l}\text { Tanpa } \\
\text { PHM }\end{array}$} & \multicolumn{2}{|c|}{$\begin{array}{c}\text { 2,5 ton. ha-1 } \\
\text { PHM }\end{array}$} & \multicolumn{2}{|c|}{$\begin{array}{c}5 \text { ton.ha }^{-1} \\
\text { PHM }\end{array}$} & \multicolumn{2}{|c|}{$\begin{array}{l}\text { Tanpa } \\
\text { PHM }\end{array}$} & \multicolumn{2}{|c|}{$\begin{array}{c}\text { 2,5 ton. ha }{ }^{-1} \\
\text { PHM }\end{array}$} & \multicolumn{2}{|c|}{$\begin{array}{c}5 \text { ton.ha }^{-1} \\
\text { PHM }\end{array}$} & \multicolumn{2}{|c|}{$\begin{array}{c}\text { Tanpa } \\
\text { PHM }\end{array}$} & \multicolumn{2}{|c|}{$\begin{array}{c}\text { 2,5 ton.ha-1 } \\
\text { PHM }\end{array}$} & \multicolumn{2}{|c|}{$\begin{array}{c}5 \text { ton.ha-1 } \\
\text { PHM }\end{array}$} \\
\hline & $\mathrm{K}$ & $\mathrm{KR}$ & $\mathrm{K}$ & $\mathrm{KR}$ & $\mathrm{K}$ & $\mathrm{KR}$ & $\mathrm{K}$ & $\mathrm{KR}$ & $\mathrm{K}$ & $\mathrm{KR}$ & $\mathrm{K}$ & $\mathrm{KR}$ & $\mathrm{K}$ & $\mathrm{KR}$ & $\mathrm{K}$ & $\mathrm{KR}$ & $\mathrm{K}$ & $\mathrm{KR}$ \\
\hline Cryptopidae & 10,7 & 28,6 & 10,7 & 20 & 5,3 & 14,2 & 10,7 & 18,2 & 5,3 & 8,3 & 5,3 & 14,3 & - & - & 5,3 & 11,1 & 21,3 & 21,1 \\
\hline Formicidae & - & - & - & - & 5,3 & 14,2 & - & - & - & - & - & - & - & - & 5,3 & 11,1 & 5,3 & 5,2 \\
\hline Gryllidae & - & - & - & - & - & - & - & - & - & - & - & - & - & - & - & - & 5,3 & 5,2 \\
\hline Lumbricidae & 16 & 42,8 & 5,3 & 10 & 10,7 & 28,7 & 10,7 & 18,2 & 26,7 & 41,7 & 26,7 & 71,4 & 26,7 & 83,3 & - & - & 16 & 15,8 \\
\hline Scarabaeidae & 10,7 & 28,6 & 37,3 & 70 & 16 & 42,9 & 37,3 & 63,6 & 32 & 50 & 5,3 & 14,3 & 5,3 & 16,7 & 37,3 & 77,8 & 53,3 & 52,7 \\
\hline Jumlah & 37,4 & 100 & 53,3 & 100 & 37,3 & 100 & 58,7 & 100 & 64 & 100 & 37,3 & 100 & 32 & 100 & 47,9 & 100 & 101,2 & 100 \\
\hline
\end{tabular}

Keterangan: PHM = Pupuk hijau Calopogonium mucunoides; K = Kepadatan Populasi (individu per m²); KR = Kepadatan Relatif (\%) 
Pemberian biochar 5 ton.ha ${ }^{-1}$ diikuti pupuk hijau Calopogonium mucunoides 5 ton.ha-1, famili scaraaeidae merupakan makrofauna tanah yang memiliki kepadatan populasi tertinggi dibanding famili lainnya, ditemukan berupa larva dan kumbang dewasa Coleoptera. Hal ini disebabkan karena sumber makanan berupa bahan organik yang berasal dari pupuk hijau Calopogonium mucunoides tersedia lebih banyak sehingga kepadatan populasi lebih tinggi. Hal ini sesuai dengan pendapat Nuryanti et al. (2016) yang menyatakan bah-wa larva kumbang badak (Coleoptera) lebih memilih serasah daun karena serasah daun memiliki kandungan gizi yang lebih komplek bagi kumbang badak. Hasil penelitian Rahayu et al. (2017) menyatakan bahwa kumbang dewasa famili scarabidae memiliki peranan sebagai herbivora. Vegetasi seperti rerumputan dan tanaman herba meningkat kelimpahannya pada reklamasi sedang (>4 tahun). Meningkat-nya vegetasi menyebabkan sumberdaya herbi-vora melimpah sehingga proporsi herbivora juga meningkat.

Pada pemberian yang sama, makrofauna tanah selanjutnya yang memiliki kepadatan populasi tertinggi adalah cacing tanah famili lumbricidae. Hal ini disebabkan cacing tanah merupakan hewan pemakan bahan organik didalam tanah sehingga dekomposisi bahan organik akan lebih cepat dengan adanya aktivitas kehidupan cacing tanah. Menurut Nuryati (2004), cacing tanah mampu mencerna bahan organik seberat dua kali lipat berat badannya selama 24 jam. Oleh karena itu, bahan organik yang berasal dari tanaman Calopogonium mucunoides dapat membantu perkembangbiakan cacing tanah.

Pemberian biochar 5 ton.ha ${ }^{-1}$ di-ikuti tanpa pupuk hijau Calopogonium mucunoides tidak ditemukan famili cryptopidae, formicidae dan gryllidae. Hal ini disebaban famili formi-cidae dan gryllidae yang dapat berpindah tem-pat untuk mencari sumber makanan. Menurut Noor (2008), semut (famili formicidae) memiliki kemampuan untuk berpindah tempat. Famili cryptopidae diduga merupakan makanan bagi beberapa predator. Baker (1998) menyatakan bahwa cryptopidae merupakan makanan bagi aves serta predator pada beberapa ekosistem yang berperan penting dalam penyeimbang ekosistem. Famili gryllidae diduga berperan sebagai predator. Menurut Heong (2002), Anaxipha longipennis (famili gryllidae) adalah salah satu predator generalis. Karindah et al. (2011) menyatakan bahwa predator generalis mampu beradaptasi dengan mudah dan dapat berkembang meskipun mangsa utama tidak tersedia, sehingga mampu berkembang lebih awal dari mangsanya.

Kondisi lingkungan juga diduga menjadi faktor yang berpengaruh terhadap kepadatan populasi dan kepadatan relatif makrofauna tanah, dimana setiap jenis makrofauna tanah memiliki adaptasi dan toleransi yang berbeda pada tiap habitatnya, sehingga makrofauna tanah yang tidak dapat bertahan hidup pada suatu habitat akan menjadi lemah bahkan mengalami kematian. Makalew (2001) menjelaskan bahwa faktor lingkungan yang dapat mempengaruhi organisme tanah yaitu iklim (curah hujan, suhu), tanah (kemasaman, kelembaban, suhu tanah, hara) dan vegetasi (hutan padang rumput). Faktor lainnya juga diduga bisa disebabkan oleh sistem saling makan antar makrofauna tanah, dimana makrofauna tanah yang tidak mampu melindungi dirinya akan dimakan oleh makrofauna tanah lainnya.

\section{Kenekaragaman Makrofauna Tanah}

Tabel 9 menunjukkan bahwa makrofau-na tanah yang diaplikasikan biochar dan pupuk hijau Calopogonium mucunoides pada gawangan kelapa sawit menghasilkan memiliki indeks keanekaragaman ( $\left.H^{\prime}\right)$ yang rendah yaitu sekitar 0,451-1,275. Hal ini sesuai dengan Magurran (1988) jika nilai $\mathrm{H}^{\prime}<5$ menunjukkan keanekaragaman yang rendah, 1,5 $<\mathrm{H}^{\prime}<3,5$ menunjukkan keanekaragaman sedang, dan H'> 3,5 menunjukkan keanekaraga-man yang tinggi.

Tabel 9. Indeks keanekaragaman $\left(\mathrm{H}^{\prime}\right)$ makrofauna tanah diantara tanaman kelapa sawit yang diaplikasikan biochar dan pupuk hijau Calopogonium mucunoides

\begin{tabular}{|c|c|c|c|}
\hline \multicolumn{4}{|c|}{ Indeks keanekaragaman $\left(\mathrm{H}^{\prime}\right)$ makrofauna tanah } \\
\hline \multirow{2}{*}{$\begin{array}{c}\text { Biochar } \\
(\text { ton.ha-1) }\end{array}$} & \multicolumn{3}{|c|}{ Pupuk hijau Calopogonium mucunoides (ton.ha-1) } \\
\hline & 0 & 2,5 & 5 \\
\hline 0 & 1,079 & 0,802 & 1,275 \\
\hline 2,5 & 0,908 & 0,919 & 0,796 \\
\hline 5 & 0,451 & 0,683 & 1,267 \\
\hline
\end{tabular}


Indeks keanekaragaman tertinggi pada pemberian pupuk hijau Calopogonium mucunoides dosis 5 ton. ha-1 diikuti tanpa biochar. Hal ini disebabkan pupuk hijau Calopogonium mucunoides mampu menyediakan sumber makanan bagi kehidupan makrofauna tanah, sedangkan tanpa pemberian biochar maupun tanpa pupuk hijau Calopogonium mucunoides tidak mampu menyediakan sumber makanan untuk makrofauna tanah.

Rendahnya indeks keanekara-gaman makrofauna tanah pada pemberian lain diduga terjadi proses saling memakan sesama makrofauna tanah seperti famili gryllidae yang berperan sebagai predator generalis. Selain itu disebabkan oleh beberapa faktor lingkungan seperti suhu tanah, kelembaban dan $\mathrm{pH}$ tanah. Keanekaragaman makrofauna tanah akan meningkat apabila bahan organik tanah juga meningkat. Sugiyarto (2000) menyatakan bahwa meningkatnya keanekaragaman makrofauna di dalam tanah dikarenakan juga meningkatnya kandungan bahan organik tanah sebagai sumber makanannya. Partaya (2002) menyatakan bahwa kelembaban tanah dapat mempengaruhi keanekaragaman fauna tanah, semakin tinggi kelembaban tanah maka keanekaragaman fauna tanah akan semakin tinggi pula. Makalew (2001) menambahkan faktor lingkungan yang dapat mempengaruhi organisme tanah yaitu, iklim (curah hujan, suhu), tanah (ke-masaman, kelembaban, suhu tanah, hara) dan vegetasi (hutan padang rumput). Faktor lainnya juga diduga bisa disebabkan oleh sistem saling makan antar makrofauna tanah, dimana makrofauna tanah yang tidak mampu melindungi dirinya akan dimakan oleh makrofauna tanah lainnya.

\section{KESIMPULAN DAN SARAN}

\section{Kesimpulan}

Berdasarkan hasil dan pembahasan disimpulkan bahwa biochar 2,5 ton.ha-1 dengan pupuk hijau Calopogonium mucunoides 2,5 ton.ha-1 meningkatkan jumlah polong per tanaman. Total individu dan jumlah populasi makrofauna tanah meningkat pada biochar 5 ton.ha-1 dengan pupuk hijau Calopogonium mucunoides 5 ton.ha-1 dengan famili sering ditemukan yaitu famili Scarabaeidae. Indeks keanekaragaman makrofauna tanah di gawangan tanaman kelapa sawit yang diaplikasikan biochar dan pupuk hijau Calopogonium mucunoides tergolong rendah.

\section{Saran}

Hasil penelitian menunjukkan bahwa pemberian biochar 2,5 ton.ha-1 diikuti pupuk hijau Calopogonium mucunoides 2,5 ton. ha-1 memberikan hasil terbaik pada jumlah polong per tanaman. Untuk itu perlu dilakukan penelitian lebih lanjut dengan memberikan perlakuan tambahan agar tercapai pertumbuhan dan produksi kedelai yang optimal. Selain itu dalam pemanfaatan lahan kelapa sawit untuk budidaya kedelai sebagai tanaman sela sebaiknya naungan yang diberikan kurang dari $50 \%$.

\section{DAFTAR PUSTAKA}

Asadi, D., M. Arsyad, H. Zahara dan Darmijati. 1997. Pemuliaan Kedelai untuk Toleran Naungan dan Tumpangsari. Buletin Agrobio, 1(2): 15-20.

Atkinson, C. J. dan Fitzgerald. 2010. Potential mechanisms for achieving benefits from tem-perate soils: a review. Plant and Soil, 337.

Baker, G. H. 1998. Recognising and responding to the influences of agriculture and other land use practices on soil fauna in Australia. Soil Ecol, (9): 303-310.

Balai Penelitian Tanaman Aneka Kacang dan Umbi. 2016. Deskripsi Varietas Unggul Kedelai. www.balitkabi.litbang.pertanian. go.id. Diakses pada tanggal 19 Januari 2018.

Cahyadi, W. 2007. Kedelai: Khasiat dan Teknologi. Bumi Aksara. Jakarta.

Cruz, P. 1997. Effect of shade on the growth and mineral nutrition of C4 perennial grass under field conditions. Plant and Soil, 188:227-237.

Farni, Y., A. R. Arsyad dan Ermadani. 2011. Aplikasi pupuk hijau (Calopogonium mucunoides dan Pueraria javanica) terhadap air tanah tersedia dan hasil kedelai. J. Hidrolitan, 2(1): 31 - 39.

Gani, A. 2009. Potensi arang hayati biochar sebagai komponen teknologi perbaikan produktivitas lahan pertanian. Iptek Tanaman Pangan, 4(1): 33-48.

Gatut, W. A. S dan T. Sundari, 2011. Perubahan Karakter Agronomi Aksesi Plasma Nutfah Kedelai di Lingkungan Ternaungi. J. Agron, 39(1):1-6.

Hakim, N., M. Y. Nyakpa., A. M. Lubis., S. G. Nugroho, M. A. Diha, Go Ban Hong dan H. H. Bailey. 1986. Dasar-Dasar IImu Tanah. Universitas Lampung Press. Lampung.

Heong, K. L. 2002. Arthropod diversity: looking beyond the ricefields. www.irri.org/Scie nce.com. Diakses pada tanggal 7 Februari 2019.

Jomol, P. M., S. J. Herbert, S. Zhang, A. A. F. Rautenkranz and G.V. Litchfield. 2000. Diffrential renponse of soybean yield components to the timing of light enrichment. Agron. J., 92: 1156-1161. 
Karindah, Sri, A. Purwaningsih, A. Agustin dan L. P. Astuti. 2011. Ketertarikan Anaxipha longipennis Serville (Orthoptera: Gryllidae) terhadap beberapa jenis gulma di sawah sebagai tempat bertelur. $J$. Entomol. Indon. 8(1): 27-35.

Laird, D. A. 2008. The charcoal vision: a winwin-win scenario for simultaneously producing bioenergy, permanently sequestering carbon, while improving soil and water quality. Agron J., 100: 178-181.

Magurran, A. E. 1988. Ecological Diversity and Its Measurement. Chapman and Hall. London.

Makalew, A. D. N. 2001. Keanekaragaman Biota Tanah pada Agroekosistem Tanpa Olah Tanah (TOT). http://www.rudyct. com. Diakses pada tanggal 10 Oktober 2018.

Noor, M. F. 2008. Diversitas semut (Hymenoptera, Formicidae) di beberapa ketinggian vertikal di kawasan cagar alam telaga warna Jawa Barat. Skripsi (Tidak dipublikasikan). Institut Pertanian Bogor. Bogor.

Novak, J. M., W. J. Busscher, D. L. Laird, M. Ahmedna, D. W. Watts, and M. A. S. Niandou. 2009a. Impact of biochar amandement on fertility of a south-eastern coastal plain. Soil Science, 174: 105-111.

Nuryati, S. 2004. Manfaat Cacing Tanah Untuk Menghasilkan Pupuk Organik. http://Berita bumi.or.id. Diakses tanggal 10 Oktober 2018.

Nuryanti, D. D., I. Widhiono dan A. Suyanto. 2016. Faktor-faktor ekologis yang berpengaruh ter-hadap struktur populasi kum-bang badak (Oryctes rhinoceros L.). Biosfera, 33(1): 13-21.

Osumi, K., K. Katayama, L. U. de la Cruz, and A. C. Luna. 1998. Fruit bearing behavior of 4 legumes cultivated under shaded conditions. JARQ., 32: 145-151.

Pahan, lyung. 2006. Panduan Lengkap Kelapa Sawit. Penebar Swadaya. Jakarta.

Partaya. 2002. Komunitas fauna tanah dan analisis bahan organik di TPA kota Semarang. Seminar Nasional: Pengembangan Biologi Menjawab Tantangan Kemajuan IPTEK. Universitas Negeri Semarang. Semarang.

Purwanto, I. 2010. Mengenal Calopogonium mucunoides sumber pupuk hijau dan bahan organik. Warta Penelitian dan Pengembangan Pertanian Indo-nesia 32 (4): 9-10.

Pusat Data dan Sistem Informasi Pertanian. 2016. Data Keluaran Komoditas. https:// aplikasi2.pertanian.go.id. Diakses pada tanggal 21 Oktober 2018.
Rachman, A., Dahria A., dan Santoso J. 2006. Pupuk Hijau. p.41-58. Dalam: R.D.M. Simanungkalit, D.A. Suriadikarta, R. Saraswati, D. Setyorini dan W. Hartatik (eds.). Pupuk Organik dan Pupuk Hayati. Balai Besar Litbang Sumberdaya Lahan Per-tanian. Badan Penelitian dan Pengembangan Pertanian. Bogor.

Rahayu, G. A., D. Buchori, D. Hindayana dan A. Rizali. 2017. Keanekaragaman dan peran fungsional serangga Ordo Coleop-tera di area reklamasi pascatambang batubara di Berau, Kalimantan Timur. J. Entomologi Indonesia, 14(2): 97-106.

Risma, Cintia. 2012. Komponen Kimia Penyusun Sel. www. scribd.com. Diakses tanggal 12 November 2018.

Salisbury, F. B. and C. W. Ross. 1995. Fisiologi Tumbuhan. Jilid II. Diterjemah-kan oleh D. R. Lukman dan Sumaryono. ITB. Bandung.

Sugiyarto. 2000. Keanekaragaman makrofauna tanah pada berbagai umur tegakan sengon di RPH Jatirejo, Kabupaten Kediri. Biodiversitas, 1(2): 47-53.

Suin, N. M. 1997. Ekologi Hewan Tanah. Bumi Aksara. Jakarta.

. 2005. Ekologi Hewan Tanah. Bumi Aksara dan Pusat Antar Universitas IImu Hayati ITB. Bogor.

Sukaesih, E. 2002. Studi Karakter Iklim Mikro pada Berbagai Tingkat Naungan Pohon Karet dan Pengaruhnya Terhadap 20 Genotipe Kedelai. Skripsi (Tidak dipublikasikan). Institut Pertanian Bogor. Bogor.

Sukartono dan W. H. Utomo. 2012. Peranan biochar sebagai pembenah tanah pada pertanaman jagung di tanah lempung berpasir (sandy loam) semiarid tropis Lombok Utara. Buana Sains, 12(1): 91-98.

Trikoesoemaningtyas, D. Wirnas, I. Widodo, L. Muhuria, D. Soepandi, and T. Takano. 2008. Maximizing genetic improvement in the selection of soybean for adaptation to low light intensity. Proceeding of the Final Seminar "Toward Harmonization Between Development and Environmental Conservation in Biological Production".74-83.

Wulandari, S., M. Sugiarto dan Wiryanto. 2007. Pengaruh keanekaragaman mesofauna dan makrofauna tanah terhadap dekomposisi bahan organik ta-naman di bawah tegakan sengon (Paraserianthes falcataria). Bioteknologi, 4 (1): 20-27. 